\title{
Los pliegues del Señor Barroco
}

\section{The folds of the Lord Baroque}

DOI: $10.12957 /$ ek.2016.25050

Dra. Alejandra González alejandra.adela.gonzalez@gmail.com.ar

Universidad de Buenos Aires | U. Nacional de Avellaneda - ARG

El caballero barroco, figura conceptual creado por Lezama Lima para pensar el barroco de la "contraconquista", se puede conectar con la idea leibniziana de pliegue. Búsqueda de una imagen como características que en la materialidad de los cuerpos humanos podrían definir otros espacios y otras temporalidades no subordinados ni a la filosofía de la historia burguesa ni a la espacialidad de las cartografías del poder de la colonial. Por último, una teoría de la imaginación latinoamericana.

PALABRAS-CLAVE Barroco. Pliegue. Imagen. Imaginación. Materialidad

The Baroque Gentleman, conceptual figure created by Lezama Lima for thinking the baroque of the counterconquest, "contraconquista", can be connected with Leibniz's idea of folding. Search of an image like features that in the materiality of the human bodies could define other spaces and other temporalities not subordinates neither to the philosophy of the bourgeois history nor to the espacialidad of the cartographies of the power of the colonial. Finally, a theory of the Latin-American imagination.

KEY-WORDS Baroque. Fold. Image. Imagination. Materiality 


\section{América es el remordimiento de España Rafael Sánchez Ferlosio}

No es un estilo, ni un movimiento de la cultura, ni un espasmo del arte, ni la decoración del siglo XVII. Más bien, un puñado de fuerzas, pulsiones desatadas, vacío amenazante recubierto por los grafismos del inconsciente. Trabajo compulsivo de la desmemoria y el afán de retenerlo todo, imposición y desgarro, barroca es la tierra con la que está hecha América, el nombre de esa herida. ¿Transferencia de la derrota ibérica? ¿Importación trasvestida? Euclides no reina en el barroco. Sus rectas se tocan, y el V postulado se abandonó para pasear por geometrías que relativizan los espacios de la metafísica clásica. Pero tampoco es moderno. Ni uniformidad ni secuencia. Más bien se curiosea por las formas canónicas de la ciencia para hacer fantasmagorías. Equívoca relación con la modernidad capitalista, que deriva en cartografías monstruosas y en tiempos heterogéneos. No se trata de una economía de acumulación sino de despilfarro. Relación ambigua con el pasado: se lo idealiza, se lo totaliza, se lo aplasta hasta hacerlo desaparecer, en un presente poroso. ¿Pliegues? Si, los del Leibniz deleuziano. Así se pliega lo hispano, vuelto América, en un Señor Barroco que mira desde las alturas el barroso agujero en que se hunde.

¿Qué mira al sesgo el Señor Barroco? Cuerpos descuartizados, antropofagias siniestras, mascaradas carnavalescas, un mapa construido sobre la diferencia entre lo humano y lo inhumano. Montaje de territorios sobre espacios des "habitados" cuando los cuerpos vivientes fueron arrojados del ámbito de la cultura al de la naturaleza. América feminizada y por eso silenciada, sometida al juego de las fuerzas inertes que la reducen a objeto escandaloso de rapiña.

Mira territorios barrocos.

\section{Los Territorios del Señor Barroco}

Para que haya territorio, reflexiona el Señor Barroco, hay que sumarle a las cualidades sensibles un significado y una comunidad que lo legitime. Nuestraamérica se vuelve colonia, estados nacionales, bloques regionales, cada vez un sentido que modifica la percepción. Batallas semánticas que no borran la herida. Todo ello bajo la ilusión conquistadora de que todo es naturaleza. Desaparición forzosa de las culturas. O rememoración folklórica. De lo que se trata es de volver inorgánicos los cuerpos, y así capa sobre capa de sentido, volver 
insignificante la muerte. No es la percepción pura, que no existe, la que delimita el cuerpo político y sensible de América.

Contra la territorialización de la conquista (con sus espacios no vacíos, sino vaciados) con su universalidad espacial y sus geógrafos, y la temporalidad unilineal y progresiva de sus historiadores, el Señor Barroco se interroga sobre el cuerpo propio y el social en la medida en que subvierte las cartografías que definen centros y periferias, adentros y afueras. Mira al sesgo, piensa desde las fronteras, multiplica tiempos y espacios virtuales y reales, potenciales, abiertos, efímeros y aplastantes. Nuevas formas de percepción, éstesis diversas, que devienen en otros modos de producción y circulación de materias y saberes en un dispositivo que cuestiona cánones de belleza y formas de intervención artística. A ese territorio, como tierra delimitada por una construcción política, se le oponen cartografías que mapean lo indeterminado, o delimitaciones que alteran los guardias fronterizos y los ejércitos nacionales. Y que articulan adentros y afueras al modo de bisagras. Trampas barrocas de una tierra que sangra horror verdadero.

Territorios de los estados nacionales. Construcción del siglo XVIII en Europa, delimitación del cuerpo terrestre en América, para llamar con el nombre Europeo a lo que quedó desmembrado y pluralmente nominado. Poder de la semántica: renominar para que vuelva a la existencia trasvestido. Entonces, el Señor Barroco se pliega sobre sí; pliegue que abre la posibilidad de la duplicación de la materia, la ubicuidad de los espacios, llena vacíos, satura y diferencia, multiplica y recorta uniformidades para crear mónadas penumbrosas y aisladas.

El problema del territorio es su condición barroca en América: es decir su carácter material, que atenta contra el espíritu europeo del imperium y la cristiandad. ¿No tiene espíritu América? No, dice el Señor Barroco, es pura metáfora, alegoría sin nombre, tierra arrasada, que se busca en todas las mitologías. Esa condición "faltante" es la que vuelve peligrosa a esa América que se vuelve antropófaga. Primero por las acusaciones que se construyen contra ella. Y luego como reacción contra la modernización impuesta. Comerse lo que viene de afuera, sin distinción de humano e inhumano, porque tal división no 
corresponde a estos cuerpos/territorios. Territorios sin voz. Tierra silenciada. Murmullos: no es lo que no puede decirse, es que no se puede decir, porque no hay palabra sino solo grito, desmesura de un imposible decir. No se trata de los enunciados sino de la enunciación. Prohibido los cuerpos que enuncian, censurados los actos de esos cuerpos, arrojados a la invisibilidad, solo resta la astucia, el escondrijo, la trasmutación, la parodia. Frente al avance de un idealismo como furia, el re-pliegue que se multiplica en las formas más redundantes de una materialidad desenfrenada. Así surge un materialismo entre los pliegues confundiendo apariencias y esencias. Atisbar en el plegado desplegado, permite hacer estéticas del sueño y del hambre, donde solo había espacio (mapas de las fundaciones y de la conquista) y tiempo (historia de los imperios). Desenfreno de una extensión no cartesiana, inextensa, impensada, imposible de ser proyectada al futuro. América no responde a su nombre, ni a las marcas de ninguna proyección Mercator, los geógrafos no alcanzan a separar los paralelos de los meridianos, no logran someter los mapas de Guaman Poma, porque algo se filtra porque no basta vaciar los ojos para que desaparezca la mirada.

El Señor Barroco no se fía de la subjetividad moderna, la envuelve en vestiduras que dejan ver en sus hilachas el cuerpo del dolor.

¿Cómo se puede establecer una delimitación de una materialidad censurada? Materia fisurada, desgarrada, porque nunca se construyó en unidad. Materia hecha de restos, territorio hecho de deshechos. La desaparición como acontecimiento es la madre de América. Materias inorgánicas sobre las materias orgánicas. El primer acto de la vida política es la decisión sobre los excrementos de una civilización. ¿Qué es basura para la América Barroca? ¿Qué se deshecha en este continente imposible, en esta isla desafortunada? Clandestinidad de los indicios, huellas, restos, formas no figuradas, materias no sustancializadas, masacre, agujero, orificio, desgarro, fisura, violación, olvido, veladura, desaparición, desnivel, grieta, abismo. Descomposición, pudrición, artesanías de un estilo en derrota. Fuera de toda posibilidad,excentrado, dislocado, agujereado... ¿Cómo aparecer desde los cuerpos convertidos en materia pútrida y la desmemoria? El territorio no es compacto, está agujereado, poroso, y la materia no es lisa, está plegada. Poetizar desde el silencio, deshabitar los cuerpos, desguazar las voces, destrabar miradas, multiplicar los focos, escandalizar hasta la locura.

Una individuación que va de singularidad en singularidad. La incomposibilidad va con un mundo en el que no se hacen figuras. Mundo de recolectores que hacen alimento de los restos o mundo de cazadores que hacen de todo un deshecho. Barroca es la forma en que la tierra se desterritorializa, porque no acepta las 
fronteras que la tajean, y se vuelve a territorializar en espacios imaginarios de comunidades siempre en retorno. Aún sin acción hay fuerza. Fuerza como presencias múltiples, como aparición, a través de un desgarro. Desde lo invisibilizado, visibilizarse, una y otra vez. Se debe tener un cuerpo. Este imperativo barroco, hace del pliegue una ética. Y es esa naturaleza sombría la que retorna como el espíritu de los muertos y hace sombra en el mercado globalizado de los vivos. Los muertos exigen al Señor Barroco sus honras fúnebres, sus mitos y sus canciones.

\section{La memoria barrosa del Señor Barroco}

Si se trata de políticas de la memoria o de obstinaciones del olvido, el barroco se debatirá entre lógicas de la dominación, organización de los recuerdos, conmemoraciones sin nombre, cartografías impuestas a los espacios coloniales, herencia obligada, dependencia histórica, evolucionismo idealista, canon y ciclos históricos.

¿Barroco antimoderno? ¿O de ambigua relación con el progreso científico? ¿Curiosidad barroca fascinada por el otro a quien supone un saber? ¿La desaparición de culturas y millones de habitantes de las "Indias" fue el daño colateral necesario para que América ingresara por el barroco mestizo a la modernidad europea? Si el barroco vino con la ciencia, el capitalismo, y la expansión colonial, no basta con tratarlo como un episodio de la historia del arte, sino como esa violenta puja que tajeó el mapa, la vieja proyección Mercator, que nos dibuja el viejo y el nuevo mundo según la filosofía burguesa de la historia. Espacio que garantiza las separaciones raciales, los centros y las periferias. Contra los estados nacionales, con su territorio de fronteras rígidas, su historia particularizante, su constitución salvaguardando la igualdad de los selectos ciudadanos ante el Uno, su nacionalidad monolinguística, contra todos ellos, la alegoría llevada al paroxismo por Lezama Lima realiza otro trabajo. Como figura retórica renuncia a su condición decorativa y se abisma en el sinsentido. Discontinúa la forma burguesa de la historia, descompone el sistema de los signos, no porque falte uno, sino porque sobreabunda sin repetir y rompe constantemente el todo. Denuncia así el fracaso de la modernización, la racionalidad y el progreso. Y por eso despliega sin cesar la disfuncionalidad del sistema. Pero el Señor Barroco ofrece una huída ante la decepción. Su contraconquista consiste en multiplicar las imágenes donde los espejos reflejan la nada del poder. Señala en su proliferación alucinada los signos de un mundo frágil y vacío, donde la 
alegoría indica la imposibilidad de un significado estable, y los residuos del mundo devuelven las astillas de una unidad imposible. El Señor Barroco se enmascara, se disfraza y de alegoría en alegoría descompleta el sentido de la historia, por medio de una imaginación desaforada atraída por el horror no del vacío sino de lo pleno tratado como nada. Perspectiva benjaminiana y paulina del tiempo: éste es el que resta, antes de que advenga el definitivo, vivir en un "como si". Lo reprimido retorna y vuelve a retornar pero no como repetición sino como diferencia. Movimiento barroco que tracciona hacia un destiempo, lo que está fuera de la línea de montaje de la producción capitalista, fuera del ciclo de los imperios y los mercados. El tiempo que resta es un sintagma que refleja una posición política: no es la servidumbre voluntaria de los discursos modernizadores, es escuchar lo que se pierde en el tráfago de los mercachifles. Cuando lo inaudible se escucha, se pone en marcha la memoria porvenir. No es una anamnesis de lo que siempre fue, nostalgia de la metafísica platónica, ni una repetición desde el saber de un ser que se va realizando, es la furiosa puesta en marcha de una comunidad de la contraconquista que devora y digiere, que habla en lenguas diversas, que socava la diferencia entre animal y humano, que profana la causalidad de la historia, denunciado sus lapsus, haciendo mofa de la linealidad, proliferando antojadiza en los bordes de una naturaleza que siempre fue cultura. Pero además, con Juana Inés, el Señor Barroco hace un elogio de la no correspondencia. La superioridad de un amor que no exige reciprocidad, fuera de toda teología de la retribución. Si no hay memoria que se corresponda con su significado único, no habrá amores que como hermafroditas platónicos encuentren su mitad después de infructuosas soledades. Solo la pregunta que Juana hace una y otra vez en una proliferación inquietante y finalmente atea. Si el mayor amor dice Juana, es el no correspondido, si el amor de Dios conlleva que no nos haga favor alguno, la memoria no puede corresponderse con una identidad silenciada o descuartizada. La memoria es el descuartizamiento y la no correspondencia entre el sentido y el dolor. Pura materia que no puede volverse discurso. Pliegue barroco de lo incorrespondido. Sin refugio ni en el pasado de una identidad, ni en el descanso de la quietud de las almas, solo resta la elaboración memoriosa. No se termina de no recordar. No será una memoria del barroco de derechas europeizante y decorativo o un barroco que intenta recuperar identidades reprimidas. ¿Será el neobarroco de la memoria nueva? ¿La presencia de fuerzas que estallan desde los recuerdos encubridores, azulejería portuguesa, interrumpida por restos que no remiten a cuerpos, que significan únicamente como herida abierta?

Toda proliferación de fuerzas, sabe Lezama, muestra un cuerpo dañado. 


\section{El Señor barroco se re- presenta}

Si solo se trata de apariencias, fantasmas, espíritus de los muertos que retornan, no basta con exorcizar al espectro de Marx, ni encontrarle nombres a los huesos. Es más bien una re-presentación que solo puede entenderse como imagen-escritura. Decodificar las cicatrices de los significantes en el cuerpo del texto como se leen las huellas que dejan los latigazos, los surcos, las muescas de los grilletes en los cuerpos vivos. Semántica del abarrotamiento, plegamientos retóricos, mitología en suma, destinada a crear un lazo indisoluble entre hispanidad y barroco. Todo ello vela con un imaginario conjunto de símbolos lo real de la herida colonial. Si el barroco es un sistema de representación, se corre el riesgo de la evanescencia del referente. Porque todo lo que es representable puede ser abolido. Y el peligro de lo que se absorbe en la apariencia de sí, es que desaparezca como cuerpo y como palabra. Las políticas de la representación siempre son violentas, porque censuran, acallan, jerarquizan, imponen un marco para lo real que solo opera como disrupción. Por eso el Señor Barroco se produce como acontecimiento de la imagen. Al no representarse más que a sí mismo, sus imágenes no dicen lo que las cosas son, porque pone todo ser en un devenir impensado, y envuelto en sus propias metáforas convierte furiosamente a las cosas en palabras y a las palabras en cosas.

Dice Lezama:

Apesadumbrado fantasma de nadas conjeturales, el nacido dentro de la poesía siente el peso de un irreal, su otra realidad, continuo. Su testimonio del no ser, su testigo del acto inocente de nacer, va saltando de la barca a una concepción del mundo como imagen. La imagen como un absoluto, la imagen que se sabe imagen, la imagen como la última de las historias posibles (Lezama, 2014, p. 53)

La escritura icónica del barroco que dibuja sus letras, sus flores, sus lágrimas y sus gotas de sangre. Alejandinho, Olguín, ¿barrocos sumisos o astutos? No es un ardid de la razón, es el modo en que las apariencias se hacen un lugar donde no lo hay, porque se desvanecieron los habitantes.

Ninguna aventura, ningún deseo donde el hombre ha intentado vencer una resistencia, ha dejado de partir de una semejanza y de una imagen; él siempre se ha sentido como un cuerpo que se sabe imagen, pues el cuerpo, al estimarse a sí mismo como cuerpo, verifica tomar posesión de una imagen. Y la imagen, al verse y reconstruirse como imagen, crea una sustancia poética, como cuna huella o una estela que se cierran con la dureza de un material extremadamente cohesivo (Lezama, 2014, p. 54) 
Pero la imagen del mestizo se transforma en el horror de un cuerpo habitado por voces que no son la propia. Debe ser educado y el teatro barroco es la pedagogía política. Tener un cuerpo, sí, a partir de una imagen. Pero ¿cuál de todas?

Representar es también acercar. El teatro religioso aborda la vida en el más allá, la aproxima al orden profano, pero también se representa la vida en las cortes, en la metrópolis, en todos los espacios negados, no solo a las clases sociales bajas sino incluso a la aristocracia criolla. ${ }^{1}$ La representación teatral en las que se muestra una débil el mundo cortesano, es el espacio donde se acomodan los personajes de la política imperial. Lo que se representa es el sueño de una sociedad integrada en un orden dado por Dios donde lo hispano es la forma superior y los indios sometidos agradecen el fin de su vida natural y su integración a la civilización. La fiesta religiosa es la representación de la asimilación imposible. Pedagogía religiosa que enseña el amor a la obediencia a Dios, al Rey, a las instituciones que normalizan el funcionamiento de una sociedad inviable. Ritualizaciones de una memoria sobreimpresa. Un barroco europeizante que funciona como un sistema de narraciones que desmemorializan. Pero a su pesar surge en el culto la figura de lo que se pretende reprimir. La fiesta popular siempre conservará ese carácter peligroso: cuando los muchos se reúnen puede que surja el efecto hueco de la risa que transvalora, que produce disonancias. Allí el aspecto revulsivo de cierto barroco, que retomará Lezama Lima. La misa se transformará a sí misma en una ritualización del origen, donde la eucaristía se convertirá en la temida escena teofágica. El espacio de la representación teatral barroca fue utilizado para dar cuenta de esa forma de domesticación espiritual, se representaba la ruina y la miseria humana, a la que se ubicaba no en la historia como un acontecimiento, sino en la metafísica ligada a la naturaleza humana corrupta. Pero esta teatralización/representación que surge en el espacio público, ¿a qué clase de barroco nos lleva?

"Estrategia de resistencia radical, el ethos barroco no es sin embargo, por sí mismo, un ethos revolucionario: su utopía no está en el más allá de una transformación económica y social, en un futuro posible, sino en el "más allá" imaginario de un hic et nunca insoportable transfigurado por su teatralización. (Echeverría, 1998, p.16)

1 Picón Salas Mariano, o. c. "la fiesta religiosa es ya desde el siglo XVI el más colorado y concreto símbolo de la fusión o choque del alma española con la indígena. Danzas, pantomimas, mascaradas o ceremonias como las que todavía acompañan en los pueblos mestizos de Suramérica a conmemoraciones tan tradicionalmente hispanas como las de Corupus Chirsti, Reyes Mayos, Nuestra Seña de Candelaria o Sna juanBautista, se incporarn en la festividad católica y hablan al espíritu indio con mayor afinidad y simpatía que lo que pudiera hacerlo el exclusivo ritual europeo." (Picón Salas Mariano, 1944, p.95) 
El barroco se construye como el refugio de los derrotados: indios desplazados de su condición humana, pero pecadores, una España vencida y pirateada que ha permitido que el oro expropiado a sus colonias se le escape de entre los dedos. El éxtasis derivado de los suplicios autoinfligidos y al sufrimiento corporal, la pobreza como cercanía a Cristo, escenificación de la muerte y del dolor, alucinación y delirio como formas de acercamiento a un más allá que evita la transformación del más acá. Las imágenes barrocas se llevan en procesiones donde se antropomorfiza la naturaleza, las imágenes cobran vida, los cánticos luctuosos se realizan en lenguas cuyos contenidos se desconocen. En medio de ese espectáculo, las limosnas y la caridad aparecen como la forma en que los ricos salvan sus almas. Los pobres indígenas son una oportunidad para la salvación de los más adinerados. Superstición e idolatría se conjugan en la representación teatral barroca que concita una guerra de imágenes, cada cual más doliente y aterrorizadora. El infierno debe ser pintado mucho más cruel que la realidad cotidiana. ¿El derrumbe violento de varias civilizaciones no es la más feroz de las invenciones barrocas? El infierno representado no es más duro que la vida de todos los días.

\section{El Señor Barroco se busca en el espejo}

Pero del cansado barroco europeo, se puede extraer el hilo de su imagen. Si, se trata de la imagen, que se impone al curso de la historia. Y el Señor Barroco está en busca de esa fábula icónica, que encuentra buscando causalidades en los pliegues del tiempo, para engendrar la materialidad de la luz. Porque la imagen engendra devenires, sin espejo el señor Barroco no puede jugar su juego de disfraces, travestimientos, transmutaciones, no habrá metáfora que valga. Donde hay una piedra hay una imagen, pero solo la metáfora transforma la piedra en espejo.

Conversión, metamorfosis en figuras alegóricas donde se pierde la divisoria entre naturaleza y cultura, esto es lo propio de la expresión americana. Es que habitamos un espacio animado, ahí donde sólo había espectros. Lezama recupera una madre naturaleza que libera a todos los entes del destino necesario. Porque luego del Renacimiento, la historia pasó a América. Y es imposible hallar en el barroco europeo, lo que el Señor Barroco muestra en nuestras tierras: tensión y plutonismo. No es la asimetría y la acumulación eurocentradas, sino esa conflictividad y ese poder desgarrador y unitivo, lo que propicia el carácter de contraconquista. El Señor Barroco se rebela revelándose como imagen proliferante, conflictiva, desgarradora. Y esto solo puede darse desde una tierra 
que revienta las costuras de los territorios, que reinventa su nombre, conflicto de la búsqueda siempre frustrada de una metáfora. Conato nunca completado para volver visible un ojo que no se presiente en su invisibilidad. Metamorfosis constantes, pliegue sobre pliegue, piedra vuelta agua, agua transmutada en sed... Ficción que se narra a sí misma y que engendra la materialidad de la letra. Se trata de enlaces que van de oscuridad en oscuridad, sin progreso imagínico alguno, recuerdo en recuerdo, que se empareja con otro, por una asociación analógica, que hace de la proliferación la base de una teoría americana de la imaginación. Furor febril que llena los espacios no por la sencilla interpretación de un horror al vacío, sino porque el Señor Barroco no padece del cansancio europeo. Retrospección o introspección, movimientos de una línea que no cesa de escribirse con "súbitos" arranques que acercan hacia otras imago. Ese repentismo es una fuerza vital que pliega una vez más el borde de la materia. Solo El señor Barroco es capaz, gracias a su condición volcánica, de explorar súbitamente comarcas analógicas. El plutonismo podría pensarse en los términos del pliegue leibniziano leído por Deleuze. El Señor Barroco sabe que es el iniciador de un tiempo, que tiene a sus espaldas la pesada carga de la conquista española y el expansionismo lusitano, imperios cargan sobre la espalda de América, pero la contraconquista es su arte. Y se apropiará de un estilo degradado y superfluo, en el curso de la historia del espíritu, para hacer de la superfluidad la materia de un mundo que se convulsiona por nacer. Formas ígneas, oníricas, mitos que se re pliegan sobre sí, y en lugar de incorporarse a la historia del arte en occidente, en un camino luminoso, se vuelven oscuras materias proliferantes que rompen las formas de la estética canónica.

El plutonismo es el que pliega y despliega en el barroco americano, por la multiplicación metafórica de sus modos de trasmutación. Sin embargo España es quien ha dejado la semilla para Lezama, pero solo pudo fructificar en América en un movimiento revulsivo, que despojado del agotado sueño europeo se posiciona como barroco emancipador, haciéndose cargo de un mito transversal que atraviesa todas las temporalidades. ¿Mito o imagen? Ambos se caracterizan por su polifonía y su unidad simultáneas. Toda la literatura y la historia universales se ubican en relación a esas metamorfosis a través de la imagen, pliegue y repliegue que se sucede y súbitamente se fragmenta o unifica.

Así cuando Deleuze plantea que el barroco no es una esencia sino una función operatoria, o un rasgo, se refiere a su capacidad de hacer pliegues, del mismo modo que Lezama. Entonces, no habría repetición de lo mismo, sino repetición de la diferencia, porque se trata de un tiempo y un espacio otro, el de una tierra arrasada, territorializada y desterritorializada, memoriosa y olvidada, dividida y trajinada por la primera globalización en el siglo XVII. 
¿Leibniz y Lezama produciendo un gran montaje? Al Señor Barroco le agradan los sistemas desplegables, entre lo de arriba y lo de abajo, entre el alma y la materia. Para ellos la materia fluye, los cuerpos son elásticos, y los mecanismos, resortes. El Señor Barroco puede corroborar como en la textura infinitamente porosa de la materia, cada pequeño elemento contiene un mundo, imágenes de sus personajes, de sus animales, de su locura botánica, de su fantasía zoológica. Pliegues orgánicas que dan cuenta de una materialidad que surge renovando el cansancio europeo a través de un repentino vitalismo. De esos pliegues surge la materia del tiempo y la diferencia histórica.

El Señor Barroco puede ver desde su lugar, el parpadeo de ser y no ser en que insiste el espacio fluctuante y agnóstico en que se mueve esta tierra territorializada, vaciada de imagen, confundida en la lisura del clasicismo, pero resistente en sus pliegues, escondrijos, desmentidas de toda esencia, contraafirmaciones engañosas. Con su retórica compleja y sobreabundante, con su infinita variedad de especies, naciones, lenguas, y sobre todo sus paisajes que alimentan una imaginación luciferina. El ornato y la superabundancia americano son una burla al ascetismo clásico, severo y riguroso. Con sus llagas rojas y sangrantes, sus oros doradísimos, sus planos contrastados de filigranas, no se describe, se inventa un mundo. Sonríe sin distinguir verdad de falsedad, y las mezcla sin tino, poniendo herejías y ortodoxias en un mismo nivel, para horror de autoridades e instituciones.

Para Lezama el barroco es cosa nuestra, ibérico por la colonización portuguesa y española. Es una estética del dolor, una curiosidad ilimitada por el mundo, una ambición fáustica de conocimiento, manifestada en el modo de estar de las culturas originarias.

“...dentro de la pobreza hispánica, era la riqueza del material americano, de su propia naturaleza, la que al formar parte de la gran construcción, podía reclamar un estilo, un espléndido estilo surgido paradojalmente de una heroica pobreza..." (José Lezama Lima, 1993, p.110)

Y somos diferentes del barroco escéptico europeo, sí, por la tensión intrínseca que nos habita y que marca formas que en lugar de llevar a la acumulación chisporrotea en los encuentros de posibles e imposibles entes (¿un cuis en la Última cena?).Difícil hoy en nuestro milenio pensar con el Señor barroco la unidad entre lo ibérico y lo originario. Pero el "plutonismo" con su carácter crítico conduce a la paradójica asimilación de los contenidos del viejo continente imperial a los que metamorfosea. Así se produce la "contraconquista". 
En la influencia americana lo predominante es lo que me atrevería a llamar el espacio gnóstico, abierto, donde la inserción con el espíritu invasor se verifica a través de la inmediata comprensión de la mirada (LIMA, 1993, p.72).

El Señor Barroco va encontrando su imagen. En oposición al jesuitismo, el nuestro se apoya en el conflicto y la transculturación mestiza con el que opera una evangelización inversa. Fenómenos de la religiosidad popular que en su sincretismo hacen convivir Pachamama y culto mariano en el manto estrellado de una misma madre. ¿Pero será el mismo cristianismo, éste plagado de dioses y de imágenes? ¿El mismo infierno, idéntico cielo? Así contra el historicismo hegeliano de la superación que conserva y niega, Lezama ve la potencia de la contradictoriedad siempre irresuelta: la evangelización culmina en un movimiento contracatequístico.

El barroco como estilo ha logrado ya en la América del siglo XVIII, el pacto de familia del inido Kondori, y el triunfo prodigioso del Aleijadinho, que prepara ya la rebelión del próximo siglo, es la prueba de que se está maduro ya para una ruptura. He ahí la prueba más decisiva, cuando un esforzado de la forma, recibe un estilo de una gran tradición, y lejos de amenguarlo, lo devuelve acrecido, es un símbolo de que ese país ha alcanzado su forma en el arte de la ciudad. Es la gesta que en el siglo siguiente del Aleijadinho, va a realizar José Martí. La adquisición de un lenguaje, que después de la muerte de Gracián, parecía haberse soterrado, demostraba, imponiéndose a cualquier pesimismo histórico, que la nación había adquirido una forma. Y la adquisición de una forma o de un reino, está situada dentro del absoluto de la libertad. Sólo se relatan los sucesos de los reyes, se dice en la Biblia, es decir, los que han alcanzado una forma, la unidad, el reino. La forma alcanzada es el símbolo de la permanencia de la ciudad. Su soporte, su esclarecimiento, su compostura. (José Lezama Lima, 1993, p. 194)

El plutonismo de Lezama Lima es un devenir constante. Si, una teoría de la imaginación americana surgida en el espacio fundado por el proceso colonizador. Condición diabólica del simbolismo propio de estas tierras. Desmesura política, ese devenir plutónico, oscilación ser/no ser, en un largo proceso que continúa su marcha sin nuestra intervención deliberada. Tierra en pugna con el estilo, América y el barroco se articulan como formas de resistencia cultural. No hay identidades perdidas o sometidas, hay búsqueda creadora de imágenes en un espejo dislocado. 
Este proceso de desjerarquización y por lo tanto de crítica institucional, ya que ejemplifica otros órdenes distintos al existente, otros mundos posibles, donde la realidad efectiva no tienen ninguna preeminencia, produce un cambalache en el sentido discepoliano, que puede ser tomado como el lamento conservador por lo que no fue, por la decepción escéptica ante el orden de lo real, o por una crítica puntual a un momento histórico determinado. Aproxima verdad, mentira y desmentida, ilusorio, imaginario y real. La plenitud es un imposible, el barroco se burla de la decepción y los decepcionados. Los yoes proliferan tras haber renunciado a una identidad consistente, hay desplazamiento y tropo, porque no hay fronteras fijas, el lenguaje se muestra articulado en las palabras que no pueden encerrar su significado en sus significantes. Polifonía, y condensación, constitución de un lenguaje poroso que no se reconoce en falta. Ningún temperamento denotativo podría controlar semejantes dislates. Por lo tanto, efectos múltiples de permutaciones, intercambios, entrecruzamientos, oxímorones. Política barrosa del juego de las combinatorias, de la producción ilimitada, de la anamorfosis y el eclecticismo. Lo que no termina de no entenderse deriva en capricho, asociación libre, aparición proliferante.

\section{Ríe el Señor Barroco}

Por eso la alegría barroca es simulacro y verdad al mismo tiempo, simulacro de unidad y verdad de la fragmentación, risa por la ruptura de lo que parecía eterno y dolor por la inestabilidad del cosmos. Trasvestimiento que socava la estabilidad del significado, la sacralidad del espacio y la ineluctabilidad de la historia. La alegría barroca, como la risa bajtiniana, da cuenta del desorden del mundo, de su inversión no complementaria, de la catástrofe del origen que retorna cíclicamente interrumpiendo progreso y sentido. La risa no es la de la comedia, es la que va de lo cómico a lo serio en un sinfín, es la que reconoce que no hay dos pulsiones, que vida y muerte forman parte de la misma cinta. ¿Moebius barroco? Claro, es el Lezama que transita su Paradiso cambiando de punto de vista narrativo, insertando relatos apócrifos, multiplicando los signos de la enunciación. Erotismo de los significantes llevado hasta el próximo de lo indescriptible. Donde el texto se hace sexualidad expresa, cae la autorialidad de la novela. Paradiso sin dioses, ni jefes de policía.

La parodia tendría un efecto político peculiar, no se burla de los acontecimientos, sino que desfigura en el inicio. Esa es la invención absoluta, que hace del caos 
latinoamericano, la tierra de la libertad. Nuestras republiquetas no serían la parodia de la República Francesa, sino una forma nueva de denunciar la imposibilidad de la representación política aún antes del fracaso del liberalismo parlamentario.

El artificio barroco puede llegar hasta la subversión de una economía, del deseo, de los signos, del capital por el procedimiento de la parodia de toda referencia. ¿Parodia que en la apariencia del respeto, descubre la sonrisa burlona del sometido? ¿Construcción de un contracanon en el interior del canon mismo, volviendo sacrílegas las imágenes, haciendo idolatría de la religión monoteísta? ¿Barroco que construye una tropología con los restos deshechos de la retórica y arma con ellos una mascarada contra el racionalismo capitalista denunciando la sinrazón que lo sostiene? La vieja embarazada, el hombre/mujer, la inversión de edades y de roles sociales, es propia de la risa carnavalesca que deshace el orden, viola las liturgias, rompe con los géneros literarios y sexuales. Se trata de otra erótica. No la economía de la escasez sino la de la superabundacia y la saturación. No se trata de figuras retóricas las que pone en juego el barroco americano sino de la carnavalización que rompe las relaciones cerradas del universo saussurano: significante/significado, signo/referente. Así, el Señor Barroco se hunde en el barro de un conglomerado de citas, intertextualidades diversas, rupturas de las isotopías estilísticas, subversión de lo real por el trabajo de lo imaginario en el orden simbólico. Orilleando anamorfosis, anagramas, caligramas, acrósticos... Invitemos a Bajtin a la mesa del Señor Barroco. El destronamiento del rey o la misa de los burros, esas fueron las ceremonias características que usaron la liturgia para desfondar las instituciones del poder. "En la base del rito de coronación y destronamiento del rey se encuentra el núcleo mismo de la percepción carnavalesca del mundo: el pathos de cambios y transformaciones, de muerte y renovación. El carnaval es la fiesta del tiempo que aniquila y renueva todo. ...Coronación-destronamiento es un rito doble y ambivalente que expresa lo ineludible y lo constructivo del cambio y la renovación, la alegre relatividad de todo estado y orden, de todo poder y de toda situación jerárquica. ... El que se corona es una antípoda del rey verdadero: esclavo o bufón, con lo cual se inaugura y se consagra el mundo al revés del carnaval."

Escrituras que se preguntan por su propio acto a la vez que pregonan su amor por los detalles de lo que es y reniegan de todo final optimista (¿alguna reminiscencia del amor fati agustiniano y su visión de la historia como inquietud en el mal?). Pero son, en todos los casos, interpretaciones sobre la relación de América con la modernidad por medio de la apropiación de un estilo surgido en el XVI europeo. Pero nuestra América descompleta lo que llega a sus manos. Cambio de sentido que transforma la crítica en disonancia. ¿La modernidad? Siempre la ambicionamos, y con un dejo de astucia, la travestimos en algo dis- 
tinto. Peligrosa política de los símbolos: convocatoria diabólica que pervierte la autoridad y trasmuta el tiempo. La modernización americana se burla de izquierdas y derechas, y decididamente no es optimista.

El Señor Barroco por más churrigueresco que se muestre no es ingenuo: no cree que éste sea el mejor de los mundos posibles ni que la historia progrese en sentido cosmopolita. Pero lo calla y compra tecnologías viejas para reciclarlas, y se emboba con estilos novedosos y los parodia. Y hace de una retórica conservadora y contrarreformada, una visión burlona de la modernidad que aún no le mostró a Europa su rostro feroz. El viejo continente tendrá que esperar al siglo XX para devorar su propia carne. Pero ya había marchitado la carne india y negra en América. Esa invención barroca es la que descree del progreso y lo desconoce adornando el presente para mitigar el dolor de un tiempo dislocado donde se pone en duda la Autoría del Mundo. El Señor barroco es agnóstico, no cree en Divinas Providencias, ni en Voluntades Históricas, ni en una Razón Ilustrada que da sentido a la vida, el dolor y la muerte. Pinta dioses sufrientes con pieles oscuras crucificados en lapachos, mientras vírgenes morenas lloran de soledad en el vientre del Cerro de Plata. No construye dogmas sobre la existencia de un paraíso más allá del mundo, lo pinta en un tiempo imposible y lo llena de volutas y gongorismos. En América la espacialidad de la tierra prevalece sobre la temporalidad de la historia. Solo con imágenes se delinean los procesos de expansión y concentración, las rupturas y continuidades, las transformaciones. Se trata de descentrar la historia multiplicando las temporalidades y cuestionando la linealidad cronológica. Ni el sufrimiento ni la alegría se someten al sentido, lo que horroriza a las autoridades debilitadas. No hay modo de justificar el horror, solo se trata de oscurecer con grafismos los espacios iluminados por la luz de la razón. El barroquismo de los cuerpos torturados o gozantes, en su estructura pasional, se muestra como signo irreductible al Sentido impuesto por un Dios, Autor o teleología última.

Ríe el Señor Barroco. Y se pierde en medio de las bifurcaciones, las divergencias de series como fronteras entre mundos incomposibles entre sí, disfruta de laberintos y criptografías naturales, hace consistencia de lo imaginario. Y entre los pliegues de sus vestiduras superpuestas, la naturaleza sombría del espíritu exige una vez más un cuerpo, y otro, y otro. Cuerpo deducido de la oscuridad del pliegue. Materia y sangre del barroco. Infinidad de plegamientos en el fondo oscuro de cada mónada que ve el infinito desde su punto de vista, desde una percepción inestable en busca de la siguiente alegoría. Mónada-metáfora de la oscuridad que exige otra vez un cuerpo. ¿Mónadas americanas? Conciencias del umbral, equilibrio siempre al borde del desequilibrio. El alma es la cárcel del cuerpo para el barroco americano. 
¿Mónadas barrocas en extraña relación de armonía universal? El Señor Barroco vela sobre ellas, a condición de no intentar dominio alguno. Continuidad plegable de la naturaleza y la escritura. Ir de lo cosmológico a lo microscópico significa ver el cosmos en la cicatriz de un latigazo.

La escritura barroca, no representa, multiplica imágenes sensoriales, despierta sensibles, posiciona fuerzas. No tiene finalidad, simplemente aparece en el espacio, lo ocupa, se hace imprescindible, rompe linealidades significantes, acontece... ¿Cómo finalizar si no hay un épico the end con una imagen que abarca todo? Porque de lo que se trata es de la multiplicación monadológica infinita de las semillas de sandía, ligadas a la vida proliferan sin sentido. Pero están en la boca de todos los comedores de sandía americanos: blanca, roja, negra, excesiva. Soledad de una escritura que acaba cuando merman las fuerzas. Escritura imagínica, plegada y desplegada en sensorialidades, puros golpes en el cuerpo, de un espíritu oscuro que se busca en su carne luminosa. Claro que el Señor Barroco es ambiguo, doble, porque pliega y despliega y no se amiga con sentidos únicos. No se trata de una lógica del deseo, sino de escribir cada vez lo deseable y lo indeseable, la más feroz mirada crítica y la aceptación de la muerte del mundo al mismo tiempo.

Recebido em: 12.05.2016 Aprovado em: 30.07.2016 Referência Bibliográfica

Echeverría, Bolívar. La modernidad de lo barroco, México DF.: Ediciones Era, 1988.

Lezama Lima, José. La expresión americana. México:

FCE, 1993.

Picón Salas Mariano. De la conquista a la independencia. México: FCE, 1944.

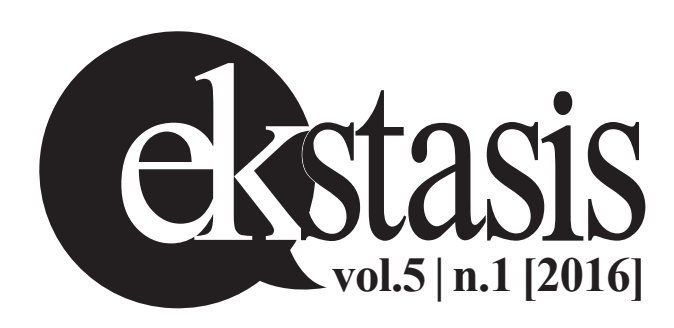

